\title{
PERAN PUBLIC RELATIONS DALAM MEMBANGUN REPUTASI PERGURUAN TINGGI
}

\author{
Yera Yulista \\ IAIN Syaikh Abdurrahman Siddik Bangka Belitung \\ yerayulista@iainsasbabel.ac.id
}

\begin{abstract}
The development of higher education institutions in Indonesia indicates the increasing meaning of education in the community so that the existence of educational institutions becomes the target for stakeholders, especially students / prospective students. In general, to maintain the existing stakeholders clearly requires the establishment of a good reputation in the community. One of the parties that can help higher education institutions in building the reputation of higher education is the presence of public relations. $P R$ represents the institution in implementing the communication program to be a bridge between the organizations represented by the university stakeholders. Keywords : Public Relations, Reputation and Higher Education
\end{abstract}

\begin{abstract}
Abstrak
Perkembangan lembaga pendidikan tinggi di Indonesia menandakan semakin meningkatnya arti pendidikan di tengah masyarakat sehingga keberadaan lembaga pendidikan menjadi incaran bagi stakehoder khususnya mahasiswa/ calon mahasiswa. Secara umum untuk mempertahankan stakeholder yang ada jelas memerlukan pembentukan reputasi yang baik ditengah masyarakat.Salah satu pihak yang dapat membantu lembaga pendidikan tinggi dalam membangun reputasi perguruan tinggi adalah dengan kehadiran public relations. PR mewakili lembaga dalam melaksanakan program komunikasi untuk menjadi jembatan penghubung antara organisasi yang diwakili dengan stakeholder perguruan tinggi.

Kata kunci : Public Relations, Reputasi dan Perguruan Tinggi
\end{abstract}

\section{PENDAHULUAN}

Sektor pendidikan selalu menjadi sector yang sangat diperhitungkan untuk membangun sebuah bangsa. Pendidikan adalah esensi membentuk kualitas sumber daya manusia yang dari kualitas tersebut maka akan dapat menghasilkan karya-karya, membentuk kepribadian yang berkarakter untuk kemasalahatan manusia itu sendiri. Salah satu pihak yang dapat membantu memfasilitasi pembentukan kualitas tersebut adalah Perguruan Tinggi. Layanan pendidikan 
Vol. 2 No. 1 Juni 2019, hal 86 - 104

formal yang paling tinggi ditengah masyarakat ini pada akhirnya diharapkan mampu mencetak generasi yang dapat memberi kontribusi pembangunan ditengah masyarakat. Perkembangan kehadiran Perguruan Tinggi khususnya di Indonesia saat ini cukup pesat. Semakin banyak pembuatan program studi baru untuk mencetak para lulusan perguruan tinggi guna menampung bidang-bidang keilmuwan yang dibutuhkan oleh masyarakat.Hal ini tentunya menjadi peluang sekaligus tantangan bagi pihak yang mengelola perguruan tinggi untuk menjawab apa yang dibutuhkan oleh masyarakat, baik pengelola pendidikan tinggi milik pemerintah ataupun yang dikelola oleh swasta.

Membahas sektor pendidikan di Pendidikan Tinggi tidaklah cukup hanya dikaji dari sudut bagaimana menciptakan proses belajar mengajar sehingga menghasilkan pendidikan yang berkualitas saja, namun berbicara sektor pendidikan dapat juga dilihat dari bisnis, arti kata bahwa apabila perguruan tinggi dikelola tetap akan berbicara bagaimana cara menggapai pasar dalam hal ini adalah calon konsumen yang dalam pendidikan tinggi adalah para calon mahasiswa itu sendiri. Kehadiran mahasiswa yang menjadi salah satu stakeholder pendidikan tinggi harus dipertahankan kehadiran mereka agar menjaga tetap adanya sebuah perguruan tinggi. Memang pada dasarnya kehadiran perguruan tinggi agar tetap eksis bukanlah satu-satunya ditentukan oleh kehadiran mahasiswa artinya semua elemen stakeholders lainnya harus tetap diperhatikan oleh para pengelola perguruan tinggi, namun tidak menampik apabila tidak ada mahasiswa lalu bagaimana akan terciptanya proses belajar mengajar itu sendiri, oleh sebab itu target pasar pada akhirnya haruslah tetap diperhatikan.

Seperti yang sudah dibahas pada pembicaraan sebelumnya adanya kebutuhan masyarakat akan pentingnya sosok agen perubahan salah satunya dari hasil pemikiran lingkungan akademisi, begitu pun para penggiat akademisi yang memerlukan ruang untuk berkontribusi ditengah masyarakat sehingga ada kesan simbiosis mutualisme maka kedua pihak baik pengelola pendidikan tinggi ataupun calon mahasiswa saling membutuhkan keberadaan perguruan tinggi. 
Apalagi Indonesia sudah memasuki era masyarakat ekonomi untuk kawasan asia dimana terjadi persaingan bukanlah hanya dilevel nasional saja namun dikancah internasional. Sumber daya manusia lintas negara semakin mudah untuk bersaing mislakan dalam bidang pekerjaan, bisnis dan sebagainya sehingga apabila tidak diperhatikan kualitas dari sumber daya manusia itu maka akan tertinggal dengan lainnya.

Beranjak dari hal tersebut maka pendidikan akan terus menjadi factor utama dalam menguatkan suatu bangsa. Dari persaingan tersebut para pengelola kebijakan pun semakin menerapkan kualifikasi tinggi untuk menduduki suatu jabatan atau peran dalam level atau bidang tertentu. Tuntutan semakin mendesak dan semakin tinggi maka masyarakat Indonesia semakin sadar bahwa kehadiran pendidikan tinggi adalah hal yang sangat penting untuk mencetak generasi berkulitas sehingga pendidikan tidaklah cukup hanya dilevel sekolah menengah atas saja namun harus di up grade untuk naik tingkat ke level pendidikan tinggi. Masyarakat tinggal memilih diantara sekian banyak pilihan lembaga pendidikan tinggi dan program studi yang banyak muncul di Indonesia.

Lembaga pendidikan tinggi yang semakin banyak muncul ditengah masyarakat menandakan bahwa semakin banyak persaingan yang ada lintas perguruan tinggi. Semua pengelola lembaga tinggi semakin sadar persaingan jelas tidak hanya ditingkat local namun juga sampai ke level internasional. Untuk dapat menarik target pasar maka sangat ditekankan perlunya memperhatikan kuliatas pengelolaan sebuah lembaga pendidikan tinggi. Pengelolaan manajemen kampus yang bagus yang akan memuaskan stakeholder jelas akan menyelamatkan keberadaan lembaga pendidikan itu sendiri. Apalagi dizaman sekarang akses teknologi komunikasi sangat pesat sehingga tidaklah sulit apabila ada mahasiswa yang ingin mengemban pendidikan lintas daerah bahkan negara, jarak bukanlah menjadi hambatan. Selama lembaga pendidikan tinggi mampu menjawab apa yang menjadi keinginan calon konsumen dalam hal ini calon mahasiswa selama mereka memiliki kemampuan maka tidaklah mengapa akses mendapatkan pendidikan dari manapun akan dengan mudah untuk dijangkau. 
Vol. 2 No. 1 Juni 2019, hal 86 - 104

Beranjak dari masalah ini hal pertama adalah kemampuan pimpinan dalam mengelola pendidikan tinggi dengan melibatkan pihak-pihak internal lembaga pendidikan untuk saling bersatu dalam menghadapi tantangan yang ada didepan mata.

Kehadiran sosok pemimpin membaca situasi persaingan harus ditransferkan kepada segala sub system internal untuk membantunya dalam membaca tantangan ini. Dapat dikatakan semua pihak harus saling bersinergi untuk menghadapi tantangan dan peluang tersebut. Kualitas dari lembaga pendidikan pada dasarnya adalah bagaimana segala sarana dan prasarana yang ada dalam lembaga pendidikan tinggi dapat menjadi motivator untuk menghasilkan proses belajar mengajar yang efektif dan efisien. Sekali lagi jika dipelihara dengan baik kualitas tersebut maka akan mampu menarik potensi pasar diantaranya calon mahasiswa untuk dapat tetap menimba ilmu di lembaga pendidikan tersebut sehingga pada akhirnya dapat merekomendasikan kepada target pasar lainnya.

Direkomendasikan atau tidaknya jelas tergantung dari cara mengelola lembaga pendidikan itu sendiri. Artinya jika reputasi yang terbentuk dalam sebuah lembaga pendidikan tinggi dinilai positif maka tanpa perlu dibayar pun oleh pihak pengguna jasa layanan pendidikan tidak akan ragu untuk membantu merekomendasikan. Lembaga pendidikan tinggi adalah sebuah system yang saling terintegrasi antara sub-sub system yang ada. Sub system terdiri dari pihakpihak yang mengelola perguruan tinggi atau yang terangkum dalam stakeholder internal yang saling bersinergi untuk membentuk suatu system yang kokoh dalam hal ini petinggi kampus, tenaga pendidik, tenaga kependidikan serta mahasiswa. Kelompok ini tentunya mengerjakan tugas masing-masing yang menjadi peran mereka dalam menjalankan fungsi guna memajukan lembaga pendidikan tempat dimana mereka bekerja.Idealnya semua harus bersatu untuk memajukan kualita manajemen dari lembaga pendidikan tinggi itu sendiri. Perlu adanya penguatan dari semua subsistem karena tentunya akan menguatkan keberadaan dari organisasi itu sendiri jika pengelolaan tidak baik jelas akan mengecilkan kualitas berdampak pada reputasi lembaga pendidikan tersebut. Ya , 
Vol. 2 No. 1 Juni 2019, hal 86 - 104

idealnya untuk menjaga kualitas dari reputasi pendidikan tinggi bukanlah hanya dibebankan pada pucuk pimpinan tertinggi namun semua pihak internal saling bersinergi agar keberadaan pendidikan tinggi itu tetap memilki reputasi positif ditengah masyarakat.

Seperti diketahui factor-faktor pembentuk reputasi dari sebuah organisasi dapat diihat dari berbagai factor sebut saja diantaranya dari identitas fisik maupun identitas non fisik organisasi, bagaimana cara mengelola organisasi, bagaimana kualitas hasil dari produk yang ditawarkan kepasar, seperti apa pola dan aktivitas dan pola hubungan sebuah organisasi. Faktor -faktor pembentuk diatas pun juga dapat berlaku dalam sebuah organisasi pendidikan tinggi.

Berbicara mengenai salah satu factor diatas dalam lembaga pendidikan tinggi yakni aktivitas dan pola hubungan sebuah organisasi maka menggambarkan bagaimana rangkaian aktivitas interaksi antara organisasi dengan pihak yang berkepentingan atau lebih popular disebut dengan publik/stakeholder. Stakeholder/khalayak adalah kelompok atau pihak-pihak tertentu yang melakukan komunikasi dengan organisasi .1yakni publik internal dan publik eksternal. Publik internal adalah pihak-pihak yang berada didalam lingkungan lembaga pendidikan tinggi sedangkan public ekternal adalah pihak luar yang diluar control lembaga pendidikan tiggi tetapi memiliki kepentingan atau kepedulin terhadap lembaga pendidikan tinggi. Kedua kelompok public ini jelas memiliki peran yang penting bagi eksistensi lembaga karena masing-masing pihak ini memiliki peran yang cukup besar dalam menjaga kestabilan lembaga. Disadari atau tidak pada akhirnya jika ada masalah yang terjadi dalam hubungan sebuah lembaga tinggi kepada public tersebut maka akan menimbulkan kepincangan alias permasalahan dalam lembaga, oleh sebab itu petinggi kampus harus sangat peka terkait hal yang berhubungan denga hubungan yang akan dibangun.

1 M.Linggar Anggoro,.Teori \& Profesi Kehumasan Serta Aplikasinya di Indonesia. (Jakarta., 2002)hlm.18 
Vol. 2 No. 1 Juni 2019, hal 86 - 104

Ada satu divisi atau departemen yang pada prinsipnya dalam profesionalitasnya berfungsi menjaga hubungan dari organisasi yang diwakilinya dengan public dari organisasi tersebut. Divisi yang biasa menjaga hubungan tersebut disebut dengan Public Relations/Humas atau dengan sebutan lainnya yakni corporate communications. Divisi inilah yang berfungsi untuk menjaga hubungan organisasi dengan publiknya agar keberadaan organisasi tetap didukung oleh publiknya dan dapat menimbulkan kepercayaan public.

\section{PEMBAHASAN}

\section{A. PUBLIC RELATIONS DALAM LEMBAGA PENDIDIKAN TINGGI}

Menurut The British Institute of Public Relations humas adalah suatu cara yang dapat digunakan untuk membangun dan memelihara saling pengertian antara organisasi dengan publiknya $^{2}$ Dari definisi ini dapat diketahui bahwa untuk menimbulkan saling memahami antara kedua pihak yakni antara pihak organisasi kepada public atau sebaliknya public kepada organisasi maka diperlukan adanya suatu cara tentunya cara tersebut adalah melalui komunikasi.

Pendapat lain mengenai definisi Humas, yakni menurut majelis humas dunia humas merupakan seni dan bagian dari ilmu social yang melakukan analisis kecendrungan-kecendrungan, memperkirakan akibat-akibat, memberikan saran kepada pimpinan perusahaan serta melakukan program perencanaan yang dapat melayani hal -hal yang menjadi kebutuhan kedua belah pihak organisasi dan khalayaknya. ${ }^{3}$ Humas didalam menjalankan profesinya tidak akan lepas kaitannya dengan menciptakan jalinan hubungan dengan kelompok manusia yang memiliki ragam karakter, ragam peran,ragam demografi , nilai dan hal lainnya. Dalam hal ini humas diminta untuk dapat berfikir analitis meghadapai kondisi social yang berubah-rubah sehingga

2 Morrisan. Manajamen Public Relations (Strategi Menjadi Humas Profesional).( Jakarta. Kencana Prenada Media Group., 2002) hlm 7

3 Ibid, hlm.8 
dengan pengetahuan yang dimilki akan menjadikan humas piawai dalam menganaliss sesuatu, mempredikd akibat-akibat apa saja yang akan muncul,dan peran humas diharapkan dapat memberikan masukan kepada pimpinan perusahaan.

Mengapa dapat memberikan masukan kepada pimpinan perusahaan? Hal ini tidak lain karena humas dianggap sebagai corong informasi sebuah organisasi. Karena dianggap sebagai corong informasi otomatis banyak pihak beranggapan Humas harus memiliki semua informasi. Humas harus melek , humas dalm hal ni mengetahui banyak hal yang berkaitan dengan lembaga tempat mereka bekerja baik dari isu-isu yang mudah terlihat bahkan isu-isu yang sangat tertutup. Oleh sebab itu Humas idealnya harus bisa pasang mata, telinga melihat isu sekitar yang ada.

Definisi humas cukup beragam tetapi benang merahnya tugas humas adalah menjaga hubungan antara organisasi dengan publiknya. Berikut diantara lima hal pokok yang menjadi tugas Public Relations :

1) Menyelenggarakan dan bertanggungjawab atas penyampaian informasi secara lisan, tertulis, melalui gambar (visual) kepada public, agar public memiliki pengertian yang tepat tentang suatu organisasi atau perusahaan, tujuan dan kegiatan yang dilakukan.

2) Humas memiliki tugas untuk memonitor, merekam dan mengevaluasi tanggapan serta pendapat umum. Selain itu humas menjalankan dan bertanggungjawab terhadap kehidupan bersama dengan lingkungan.

3) Memperbaiki citra sebuah organisasi, PR harus menyadari citra yang baik tidak hanya dinilai dari bentuk gedung, presentasi, dan seterusnya tetapi juga pada a). bagaimana organisasi dapat menjadi cerminan organisasi yang dipercayai, memiliki kekuatan, mengadakan perkembangan secara berkesinambunagn yang selalu terbuka untuk dikontrol b). dan citra tersebut merupakan gambaran komponen yang kompleks. 
4) Tanggung jawab sosial. PR merupakan instrument untuk bertanggung jawab terhadap semua kelompok yang berhak terhadap tanggung jawab tersebut.

5) Komunikasi. PR mempunyai bentuk komunikasi yang khusus, adanya komunikasi timbal balik, maka perlu memiliki pengetahuan tentang komunikasi. Dalam fungsinya komunikasi itu sentral. 4

Berbicara mengenai keberadaan humas dalam lembaga pendidikan tinggi sama pentingnya ketika membahas peran Humas/PR dalam organisasi lainnya karena mereka adalah pihak yang langsung bersentuhan langsung untuk berinteraksi dengan semua lini public. PR lembaga pendidikan tinggi harus mengetahui apa yang menjadi kebutuhan dari masing-masing dari public.Jika kemudian kebutuhan-kebutuhan tersebut diketahui maka PR harus menyampaikan kepada pihak-pihak yang dapat memenuhi kebutuhan tersebut sehingga jika kebutuhan-kebutuhan tersebut dapat diakomodir dengan baik maka akan menimbulkan kepuasan bagi pihak public sehingga reputasi positif organisasi pun dapat tercapai. PR dalam pekerjaannya adalah menjual reputasi. Menjual reputasi yang merupakan akumulasi dari citra adalah bentuk jual yang bisa dikatakan tidak terlihat secara langsung walaupun bisa dikatakan secara implisit namun memiliki damapak yang sangat besar bagi sebuah organisasi. Dalam hal ini Humas perguruan tinggi harus dapat bekerja sama dengan divisi manapun guna mencapai tujuan dari pencapaian repuatsi positif itu sendiri.

Fungsi utama kehadiran Public Relations adalah 1)Dapat menciptakan serta mengembangkan hubungan baik antara organisasi dengan stakeholder baik pihak dalam atau luar organisasi 2) Dapat menanamkan pengertian sehingga dapat memotivasi untuk menumbuhkan motivasi dan partisipasi

${ }^{4}$ Sr. Maria Assumpta Rumanti OSF. Dasar-Dasar Public Relations (Teori dan Praktik). (Jakarta : Grasindo.,2002), hlm.42 
public dank e 3) dapat menciptakan opini public yang menguntungkan kedua belah pihak . ${ }^{5}$

Lebih spesifik ada dua fungsi dari humas perguruan tinggi yakni :

1. Fungsi membangun (konstruktif ). Dari fungsi ini perguruan tinggi dapat membagi aspek keilmuwan sebagai metode untuk dapat memecahkan masalah yang dapat diterima masyarakat, dan kebijakan perguruan tinggi bisa diterima segenap civitas akademika

2. Funsi korektif. Berdasarkan fungsi ini humas harus mampu menetralisir setiap opini negatif yang berkembang di publik internal maupun ekstrenal. Dari fungsi ini adanya usaha agar perguruan tinggi tidak melakukan sesuatu yang dapat merugikan organisasi. Selain itu juga memberikan input yang diperlukan dalam mengambil kebijakan. ${ }^{6}$ Fungsi-fungsi ini jika dijalankan dengan baik maka akan mengokohkan hubungan dengan publik.

\section{B. Mengapa Perlu Menjaga Hubungan dengan Publik?}

Hubungan dengan publik mengapa perlu dijaga? Karena hubungan yang dijaga jelas akan menguatkan hubungan itu sendiri dan untuk menguatkan hubungan tersebut tidak akan lepas dari aktivitas bernama komunikasi. Begitupun juga dengan perguruan tinggi perlu menjaga hubungan tersebut baik kepada pihak internal maupu pihak eksternal lembaga. Hubungan dengan public haruslah dipelihara dalam hal ini harus dijaga dengan hal yang dapat dilakukan oleh Humas/PR adalah membuat programprogram komunikasi yang terencana dan berkesinambungan untuk menjaga agar hubungan itu agar selalu dekat, dan bernilai. Komunikasi yang dibangun dalam bingkai membangun hubungan tersebut bukanlah hanya sekadar komunikasi biasa namun komunikasi yang menimbulkan kepuasan baik pihak organisasi ataupun pihak publik sebaliknya.

${ }^{5}$ Ibid.hlm 237 hlm. 221

6 ASPIKOM..Komunikasi dan Isu Public Cetakan Pertama. (Yogyakarta : ASPIKOM., 2015), 
Vol. 2 No. 1 Juni 2019, hal 86 - 104

Humas dalam perguruan tinggi harus dapat membuka jaringan sebanyak mungkin dan menjaga hal tersebut guna memaksimalkan hubungan tersebut, memang berangkat dari menjaga hubungan ini humas lembaga pendidikan tinggi perlu mengenal siapa saja publik yang memiliki kepentingan dengan lembaga, dapat memetakan kelompok-kelompok public dan mengetahui apa saja yang menjadi kebutuhan dari masing-masing kelompok publik.

Ada beberapa alasan mengapa perlu diadakannya pemetaan stakeholder pertama untuk memudahkan dalam mengidentifikasi stakeholder mana yang menjadi sasaran utama dari program kehumasan, kedua, untuk dapat menciptakan skala prioritas hal ini karena adanya pembatasan untuk anggaran dan sumber daya lainnya , ketiga, dapat memilih media atau teknik humas yang dapat digunakan dan keempat untuk mempersiapkan pesanpesan agar mudah diterima oleh khalayak. ${ }^{7}$ Berikut dalam table dibawah ini penulis mengelompokkan public internal dan eksternal yang ada di perguruan tinggi:

\begin{tabular}{|l|l|}
\hline \multicolumn{1}{|c|}{ Publik Internal } & \multicolumn{1}{c|}{ Publik Eksternal } \\
\hline Pimpinan & Lembaga Pendidikan lain \\
\hline Dosen (Tenaga Pendidik) & Pemerintah \\
\hline $\begin{array}{l}\text { Pegawai dan Keluarga Pegawai } \\
\text { (Tenaga Kependidikan) }\end{array}$ & Media Massa \\
\hline Mahasiswa & Masyarakat \\
\hline Orang tua/Wali murid mahasiswa & Alumni Perguruan Tinggi \\
\hline & Calon mahasiswa \\
\hline & $\begin{array}{l}\text { Industri } \\
\text { (perbankan/asuransi) }\end{array}$ \\
\hline
\end{tabular}

7 M.Linggar Anggoro,.Teori \& Profesi Kehumasan Serta Aplikasinya di Indonesia. (Jakarta., 2002)hlm.23 
Vol. 2 No. 1 Juni 2019, hal 86 - 104

Masing-masing dari public ini memiliki karakter masing-masing dan memiliki kebutuhan masing-masing. Pengelola perguruan tinggi dalam hal ini pihak pimpinan harus memahami apa yang menjadi tolak ukur kepuasan public kepada organisasi, dan pihak lembaga harus bisa mewujudkannya dan hal ini salah satunya dapat difasilitasi oleh kehadiran Public Relations. Namun apabila hal sebaliknya terjadi dalam hal ini organisasi bersikap "acuh" terhadap publik, sekadar saja dalam memperlakukan publik, menyamakan semua kebutuhan public yang pada dasarnya kebutuhan publik itu berbeda maka dikahawatirkan akan menimbulkan resiko. Berikut beberapa hal yang dapat terjadi jika tidak dilakukannya pemetaan kepada public :pertama )Usaha dan dana kehumasan dapat terpecah belah karena terlalu luasnya stakeholder yang akan dituju kedua) Pesan yang dikirimkan bisa jadi tidak ditangkap dengan maksimal, karena tidak sesuai dengan karaketristik khalayak ketiga) Jumlah kegiatan tidak sesuai dengan jadwal yang telah ditetapkan sehingga penggunaan jam kerja, materi dan peralatan menjadi tidak ekonomis keempat) Hal yang menjadi tujuan utama dapat luput dari jangkauan kelima) Pihak manajamen atau perusahaan klien merasa tidak puas dengan hasil yang ada ${ }^{8}$

Membaca dari resiko yang dapat terjadi apabila tidak dapat memetakan public secara maksimal maka pada akhirnya akan mengancam lembaga itu sendiri. Humas dapat saja melakukan penelitian baik yang bersifat informal atau formal untuk mendapatkan informasi-informasi terkait kebutuhan para stakeholder, jadi bukan hanya sekadar asumi (perkiraan saja). Karena didapatkan dari hasil penelitian jelas informasi itu akan bersifat valid dan dapat dijadikan rujukan bagi lembaga untuk menginvetarisir apa yang menjadi kebutuhan publik. Humas harus dapat bekerja sama dengan segala pihak guna mencapai tujuan dari organisasi.

Apabila melihat dari pihak publik internal kepuasan para pimpinan perguruan tinggi adalah agar apa yang menjadi visi misi lembaga pendidikan 
Vol. 2 No. 1 Juni 2019, hal 86 - 104

secara menyeluruh dapat tercapai, indicator kepuasan dosen selaku tenaga pendidik adalah dapat dengan maksimal mengerahkan potensi menjadi pendidik disertai dengan dukungan fasilitas lembaga dan dapat menerima gaji sesuai dengan aturan yang berlaku.Sedangkan bagi mahasiswa dan orang tua mahasiswa indicator kepuasan bagi mereka adalah agar dapat maksimal dalam proses menerima ilmu di perguruan tinggi yang tentunya didukung oleh fasilitas sarana dan prasarana yang memadai sehingga proses belajar megajar dapat dengan mudah dijalani.

Melihat publik eksternal yang lebih beragam dan merupakan pihak yang terlihat tidak memiliki dampak langsung dengan keberlangsungan sebuah organisasi walaupun pada praktiknya sangat berpengaruh,maka terdapat beberapa jenis indicator kepuasan dari kelompok public ini misalkan untuk lembaga pendidikan lain dapat merasa puas apabila lembaga pendidikan tinggi yang bersangkutan bukan menjadikan "mereka” sebagai ancaman karena posisi mereka sama-sama perguruan tinggi sehingga diwarnai persaingan yang tidak sehat namun harapannya dapat menjalin kerjasama antar lintas pergurun tinggi, bagi pemerintah mengukur dari sisi apabila perguruan tinggi dapat mengikuti segala peraturan hukum dengan patuh sesuai dengan amanat pemerintah,bagi pihak industry dapat menggunakan jasa mahasiswa/alumni untuk ikut bergabung dengan perusahaan mereka sedangkan masyarakat kategori kepuasan mereka terhadap perguruan tinggi ketika lembaga tersebut dapat memberikan kontribusi kepada masyarakat dari hasil pemikiran para akademisi. Pada dasarnya jenis serta jumlah dari dari kelompok public dari masing-masing pergurun tinggi bisa jadi berbeda satu sama lainnya tetapi yang terpenting adalah bagaimana organisasi dapat menjawab apa yang menjadi kebutuhan para stakeholder. 


\section{Manajemen PR dalam Pengelolaan Perguruan Tinggi}

Humas adalah bagian dari manajemen organisasi. Keberadaanya harus menjadi perhitungan pimpinan perguruan tinggi, tidak bisa dipandang sebelah mata. Idealnya posisi humas dalam suatu struktur organisasi adalah memiliki divisi tersendiri yang berpisah (tidak tergabung dnegan divisi lainnya namun dalam lintas structural menduduki garis koordinasi yang lebih dekat dengan pimpinan perguruan tinggi dengan harapan agar lebih mudah koordinasi antara pihak Humas dengan pimpinan perguruan tinggi sehingga akan lebih mudah pula dalam membuat sebuah kebijakan terkait kepentingan organisasi, hal ini mengingat humas pada dasarnya memiliki peran sebagai penasehat ahli, dalam hal ini PR dianggap memiliki kemampuan oleh pihak manajmen sehingga pihak manajemen cukup bersifat pasif sehingga menerima apa ayang direkomendasikan oleh PR .Selain memiliki peran diatas Humas juga berperan sebagai fasilitator komunikasi dalam hal ini PR berperan sebagai pihak yang mampu mendengarkan apa yang ingin diharapkan oleh publik, dan dapat menyampaikan apa yang dinginkan pihak organisasi kepada public internal atau eksternal. Dengan harapan dari hal ini dapat mengutamakan hubungan antar organisasi dengan publiknya. Peran yang ketiga dari PR adalah sebagai fasilitator proses pemecahan masalah, yakni PR dapat membantu pihak pimpinan dalam mengatasi masalah yang dihadapi oleh suatu organisasi.Dan peran keempat PR berperan sebagai teknisi komunikasi disini PR dapat berperan sebagai journalist in resident yang lebih mengarah kepaa pelayanan teknis komunikasi. ${ }^{9}$

Dapat dilihat peran PR diatas cukuplah strategis peran PR bagi para pimpinan organisasi.Apabila posisi humas tidak dibuat dalam posisi yang strategis alias hanya ditempatkan dalam level rendah garis koordinasi yang jauh dengan pimpinan perguruan tinggi maka sulit pula koordinasi apalagi dalam membuat sebuah wewenang dalam membuat keputusan. Posisi yang

9 Firsan Nova.Crisis Public Relations. Strategi Menghadapi Krisis, Mengelola Isu, Membangun Citra dan Reputasi Perusahaan ( Jakarta :Rajawali Pers., 2011). Hlm.58-59 
Vol. 2 No. 1 Juni 2019, hal 86 - 104

rendah jelas akan sulit untuk berkoordinasi karena Humas memiliki keterbatasan dalam memutuskan sebuah keputusan. Humas adalah bagian dari sub unit organisasi artinya apabila ada celah dalam mengelola organisasi secara tidak maksimal maka akan berakibat pula dalam pembentukan reputasi yang negatif. Hal ini harus disikapi dengan cerdas khususnya bagi level pimpinan.

Namun sayangnya masih ada anggapan bahwa Humas tidak harus strategis kedudukannya dalam sebuah pengelolaan perguruan tinggi, PR hanya dilibatkan dalam llevel peran sebagai teknisi komunikasi saja yakni hanya sebatas melakukan pendokumentasian, foto, kliping. Ada beberapa alasan mengapa PR hanya berada di level tersebut:

1) Rendahnya pemahaman pimpinan terhadap fungsi dan peran humas, sehingga PR di perguruan tinggi kurang diberdayakan oleh petinggi kampus. Hal inilah dapat menyebabkan posisi humas perguruan tinggi tidak berada pada tempat yang strategis;

2) Masih adanya anggapan bhawa Humas masih dikategorikan sebagai bagian yang tidak terlalu penting terhadap perkembangan organisasi;

3) Kurang pemahaman tentang humas di perguruan tinggi secara lembaga maupun posisional;

4) Penempatan staf humas tidak yang tidak disandingkan dengan kemampuan pemahaman dan ketrampilan kehumasan;

5) Anggaran (dana) untuk kegitan dan program kerja humas ynag tidak memadai ${ }^{10}$

Idealnya posisi Humas haruslah strategis. Dalam mengelola perannya sebagai bagian dari manajemen sebuah organisasi maka humas pun secara spesifik harus dapat mengelola manajemen humas.Manajemen humas adalah penelitian, perencanaan, pelaksanaan, pengevaluasian suatu kegiatan komunikasi yang disponsori oleh organisasi mulai dari pertemuan kelompok

${ }^{10}$ ASPIKOM..Komunikasi dan Isu Public Cetakan Pertama. (Yogyakarta : ASPIKOM., 2015), 
Vol. 2 No. 1 Juni 2019, hal 86 - 104

kecil hingga berkaitan dengan konferensi pers internasional via satelit, dari pembuatan brosur hingga kampanye nasional melalui multimedia, dari menyelenggarakan acara open house hingga kampanye politik, dari pengumuman pelayan public hingga menangani kasus manajemen krisis. ${ }^{11}$ Dari definisi jelas kegiatan pengelolaan humas untuk menghasilkan suatu program kerja komunikasi melewati banyak tahap panjang yang harus dilewati dari penelitian hingga tahap evaluasi.

Berikut tahapan penjabaran manajamen Humas dalam sebuah organisasi:

1. Menentukan masalah (defining the problem)

Untuk dapat menentukan masalah apa yang terjadi dalam sebuah perguruan tinggi maka humas harus dapat menemukan masalahnya melalui pencarian fakta dilapangan, sekecil apapun masalah yang ada dilapangan harus ditemukan akar permasalahannya jangan sampai akan mengancam reputasi sebuah organisasi. Dalam tahap ini yang akan diteliti adalah pengetahuan, pendapat, sikap dan tingkah laku khalayak yakni bagi pihak -pihak yang memiliki kepentingan atau pengaruh oleh tindakan organisasi .

Sudah selayaknya humas tahu tentang keadaan sekitar kampus karena Humas dianggap sebagai pusat informasi, maka humas harus mengetahui seluk beluk yang terjadi dalam organisasi sekecil apapun itu, dalam hal ini humas tidak boleh menganggap rendah informasi ini. Fact finding pada dasarnya harus dapat menemukan masalah yang terjadi dilapangan. Ada beberapa metode yang dapat ditemukan guna mendapatkan informasi dilapangan yakni lewat sebaran angket/ kuesioner, observasi, wawancara, forum discussion group dan sebagainya. Data dilapangan ini akan menjadi sebuah rujukan bagi program humas selanjutnya. Sebenarnya bisa saja humas melakukan pekerjaan tanpa melakukan penemuan masalah dilapangan namun apa jadinya jika

${ }^{11}$ Sari Nilla Wahyu Betty. Humas Pemerintah. (Yogyakarta: Graha Ilmu,2012), hlm.22 
Vol. 2 No. 1 Juni 2019, hal 86 - 104

melakukan suatu program komunikasi tanpa melakukan penelitian terdahulu dikhawatirkan akan munculnya kesia-siaan. Dari tahap ini lah humas akan beranjak dalam membuat keputusan tentang hal apa saja harus dilakukan dalam program komunikasi nantinya karena hasil penelitian adalah hasil yang murni didapatkan, terdapat objektivitas disana , transparansi disana. Dari hasil riset inilah nanti nya dapat ditemukan apa yang menjadi kelebihan ,kekurangan,peluang ataupun ancaman yang didapatkan. Sekali lagi penilaian ini lah yang akan menjadi modal untuk membuat sebuah perencanaan. Humas perguruan tinggi harus bisa proaktif untuk menjemput masalah yangada dilapangan.

2. Perencanaan dan Penyusunan Program (Planning and Programming)

Tahap kedua ini digunakan sebagai tahapan mengelola masukan dari hasil penemuan masalah dilapangan yang akan dirangkum dalam bentuk perencanaan. Perencnaan adalah sebuah tahap menuju pelaksanaan. Perencanaan adalah tahap Humas perguruan tinggi harus bisa membuat perencanaan tentang hal yang diperlukan agar kegiatan humas dapat berjalan sesuai dengan yang dijadwalkan, perencanaan pada dasarnya berfungsi untuk membatasi tujuan. Perencanaan dibuat tentunya berdasarkan hasil temuan yang ada dilapangan.Hasil temuan dilapangan itulah yang nantinya akan menjadi sebuah ide untuk membuat langkah selanjutnya.

Perencanaan dalam sebuah organisasi pada dasarnya terdiri dari dua jenis yakni perencanaan strategis dan perencanaan taktis. Perencanaan strategis adalah perencanaan yang sifatnya jangka panjang dibuat oleh para manajemen tingkat atas. Hal yang biasa diangkat dari perencanaan strategis ini adalah tentang tujuan utama dari organisasi dan kebijakan yang akan diimplementasikan sedangkan perencanaan kedua adalah jenis perencanaan dalam mengimplementasikan keputusan spesifik 
yang telah dirancang dalam perencanaan strategis. ${ }^{12}$ Public Relations dalam hal ini harus bisa mengintegrasikan ke dua hal ini agar tetap berjalan dengan baik.

3. Aksi dan Komunikasi (taking action and communicating)

Tahap ketiga ini berupa aktivitas melaksanakan tindakan dan komunikasi yang sudah dirancang sejak awal untuk mencapai sebuah tujuan tertentu. Aksi adalah tindakan nyata yang dapat dilakukan untuk mengeksekusi kegiatan komunikasi tersebut, maka yang pelu dilakuakn adalah melaksanakan kegiatan tersebut. Dalam hal ini harus disesuaikan jumlah personil yang akan terlibat daam kegiatan tersebut dan pekerjaan yang dapat dilakukan sesuai dengan kompetensi masing-masing.

4. Evaluasi program (evaluating the program)

Tahap terakhir ini adalah berupa evaluasi yang sangat diperlukan sebagai bahan untuk menilai apakah pelaksanaan program sudah berjalan seperti yang diharapkan atau belum. Langkah ini berupa evaluasi atas persiapan, pelaksanaan dan hasil-hasil program. Humas perlu mengevalusi setiap kegiatan yang sudah berjalan karena hal ini akan berpengaruh terhadap pelaksanan diwaktu selanjutnya.Humas perlu mengevalusi dengan jujur hal yang sudah terjadi untuk menjadi bahan perbaikan tentunya.

Menurut Mark P Elreath riset kehumasan dalam tujuannya untuk evaluasi dapat dibagi menjadi dua bagian yakni evaluasi bersifat tertutup dan evaluasi terbuka. Evaluasi yang bersifat tertutup berfokus pada evalusi kepada pesan dan kegiatan yang direncanakan untuk kampanye serta seperti apa dampak yang muncul pada publik yang sedang dituju. Tujuan dari evaluasi ini adalah untuk menguji pesan dan media kampanye sebelum disampaikan kepada khalayak yang dituju. Selanjutnya evaluasi yang kedua adalah evaluasi yang sifatnya terbuka, dalam system evaluasi

12 Dan, Lattimore, dkk. Public Relations Profesi dan Praktik Edisi 3.( Jakarta: Salemba Humanika,2010) Hlm.130 
ini adalah berusaha untuk memasukkan faktor yang berada diluar kontrol kampanye Public Relations ketika menilai efektivitasnya. Dalam sistem evaluasi ini lebih terfokus kepada keluasan dari fungsi PR itu sendiri yang dilingkupi dari berbagai aspek organisasi atau lingkungannya 13 dan ada beberapa teknik yang dapat digunakan untuk mengukur efektivitas dari kegiatan Public Relations yakni :Liputan media massa dan pengaruhnya,ukuran kegiatan (dari suatu event), pesan berbasis web, penguatan reputasi perusahaan, mulut ke mulut dan media social lainnya .${ }^{14}$ Tentunya semua metode ini harus dapat di kuasai oleh humas guna mendapatkan hasil evaluasi yang akurat.

\section{KESIMPULAN}

Pada prinsipnya adalah semua tugas publik internal saling bersinergi dalam menjaga reputasi perguruan tinggi,walaupun secara lebih khusus menjadi tanggungjawab PR. Humas posisinya sangat penting menjadi mediator dalam membina hubungan antara organisasi yang diwakilinya dengan publik lembaga. Humas harus bisa menjaga komunikasi karena hal itu menjadi kunci agar pondasi suatu hubungan menjadi kuat sehingga reputasi perguruan tinggi agar selalu terjaga melalui beragam pendekatan komunikasi kepada semua publik perguruan tinggi yang diwakilinya.

\section{Daftar Pustaka}

ASPIKOM. 2015.Komunikasi dan Isu Public Cetakan Pertama. ASPIKOM: Yogyakarta

Anggoro, M.Linggar. 2002.Teori \& Profesi Kehumasan Serta Aplikasinya di Indonesia. Jakarta: Bhumi Aksara

Kennedy, John.E dan Soemanagara, R. Dermawan.2006. Marketing Communication Taktik dan Strategi. Jakarta :Bhuana Ilmu Populer Kelompok Gramedia

13 Ibid. Hlm 185 dan 188

14 Ibid. HIm 179 
Jurnal Ilmiah Sustainable

Vol. 2 No. 1 Juni 2019, hal 86 - 104

Lattimore, Dan, dkk.2010. Public Relations Profesi dan Praktik Edisi 3. Jakarta: Salemba Humanika

Morrisan.2008. Manajamen Public Relations (Strategi Menjadi Humas Profesional). Jakarta. Kencana Prenada Media Group

Nova, Firsan.2011.Crisis Public Relations. Strategi Menghadapi Krisis, Mengelola Isu, Membangun Citra dan Reputasi Perusahaan. Jakarta :Rajawali Pers

OSF Rumanti Assumpta Maria Sr. 2002. Dasar-Dasar Public Relations (Teori dan Praktik). Jakarta : Grasindo

Sari Nilla Wahyu Betty. 2012. Humas Pemerintah. Yogyakarta: Graha Ilmu 